two sides to the problem of weeds. Weeds are not entirely bad. Nature abhors a vacuum. If we leave the soil bare and subject to erosion, weeds are usually the first plants to move in and cover it. Far better a patch of weeds than an unsightly area of eroded soil. Man can control weeds but he cannot make soil. When unproductive fields are abandoned or other soil left bare the first plants to cover it are usually annual weeds. These are followed by perennial weeds which, in turn, ultimately are succeeded by the native vegetation of the region.

Pastures on native grassland are frequently overgrazed today, as in past centuries, to the extent that palatable plants become seriously depleted while unpalatable weeds such as pasture sage, broomweed, etc., increase in density and size. When asked how to kill these pasture weeds I always advise the removal of the cause first. In a way those weeds are protectors of the pasture. By their abundance they indicate the fact of overgrazing. They aid the recovery of native grasses by holding snow and reducing wind and water erosion. Ultimately they revert to their ncrmal position as a minor component of the native vegetation. Good husbandry will keep weeds under control as well as provide the farmer with a fair return from the land under his care.

It is well to be mindful of the probability that there will always be weeds. Man is continually disturbing the land surface, attempting to grow plants of his own choice in areas where other plants normally occur. The latter he calls weeds. In many instances those weeds are beneficial to him. Before destroying them he should stop to consider why they are present and, if possible, first remove the causes. Weeds, as I have indicated, are often nature's method cf correcting man's mistakes.

\title{
Snowy Plover Taken in Saskatchewan
}

\author{
by Douglas E. Wade, Regina
}

On May 31, 1964, a Snowy Plover (Charadrius alexandrinus) was discovered by my wife, Dorothy R. Wade, at Buck Lake, 18 miles south of Regina. Later the same day, at our request, the plover was collected by Elmer Fox of Regina. Robert W. Nero, ornithologist on the Regina Campus of the University of Saskatchewan, who prepared the specimen (a male) as a study skin, submitted it for subspecific determination to W. Earl Godfrey, Acting Chief Zoologist, National Museum of Canada, who identified it as the western race of Snowy Plover, Charadrius alexandrinus nivosus (Cassin). This race is confined largely to the Pacific coast from southern Washington to southern Lower California and inland from northern Utah and Kansas south to New Mexico and northern Texas. An eastern race, C. a. tenuirostris (Lawrence), is found in the Gulf States from Florida to Texas and in Cuba and other islands.

The Snowy Plover has been collected but twice previously in Canada; a specimen was taken in Toronto, Ontario, May, 1880, and again in the same city in July, 1897 (Bent, 1929 ); both have been assigned to the eastern race (A.O.U., 1957). The casual or accidental records for the western race include Wyoming and Nebrask'a (A.O.U., 1957), but Peterson (1961) includes Montana and omits Nebraska. Its occurrence in Saskatchewan must also be regarded as accidental.

Buck Lake, where the Snowy Plover was found, has been one of our favorite birding areas during the past four years. Not one of our trips there has been disappointing. We think of Buck Lake as a "bald" lake cn "bald prairie", although the treeless plains are practically all wheat fields with some farm buildings and tree wind-breaks nearby to the west and the southwest. Here is a neat, clean-cut prairie pothole lake. As you drive down the road you don't see the lake until you are almost into the depression. The lake is circular, shallow and muddy-looking; it and the exposed mud beach that growis quite wide during drouthy spells have very little marsh or aquatic 
vegetation. There must be a reason for this barrenness, but we haven't figured it out. Here is one of the few pieces of water south of Regina for 25 miles that hasn't been drained away or dried up entirely since 1956 . Although it fluctuates in size it is now about 130 acres.

On that afternoon of Sunday, May 31 st, we were the only birders in the vicinity. We had gone down about 3:00 p.m. primarily to get a count on the Canvasbacks. It was a good day to be out birding. A north wind scarcely rippled the surface of the lake; the sky was clear overhead and the air temperatures were in the mid sixties. It was, however, one of those days on the prairie when distant buildings and wind-breaks seemed to float free and appeared bulkier and taller than they actually were. In the right places you might get some good mirages; for instance, the Dirt Hills 15 to 20 miles to the west loomed up like a mountain range. At close range around the lake, the day wasn't hot enough to affect our birding with heat shimmers.

We spotted a few Mallards, Pintails, Gadwalls and Widgeon; and there were about 50 Ruddy Ducks and one Western Grebe, some Eared Grebes and two Pied-billed Grebes to be seen. We counted at leasit two dozen Lesser Scaup and 40 Bluewinged Teal. The teal were packed into small groups and were staying close to shore. Four male Buffleheads stood out, even though they were on the far side. One female merganser, probably a Red-breasted, swam along at a brisk pace. There was a mixed flock of over a hundred Ring-billed and Franklin's Gulls. Although not abundant, Black and Common Terns were noticeable in flight and sound as they quartered the lake. Blackbirds were noticeably uncommon.

Along the shore near us, two pairs of Willets and two pairs of Marbled Godwits fed. Around the lake there were, we estimaited, about 50 American Avocets; we knew of at least four Avocet nests, each with four eggs. Four other Avocets, which we thought were nesting, would, when flusined, lead us away with a brokenwing display or "feeding antics" such as moving along in shallow water sweeping the bill sideways.

Across the lake we could easily make out the pattern of Black-bellied
Plovers, and we counted precisely $4 i$ Four or five flocks of Sanderling eight to ten each, were constantl cruising the shore and tcuching dow to feed. We marvelled at the spee afoot shown by individual Sander lings dashing after one another. A least three Spotted Sandpipers traile with the Sanderlings. One lone Dun lin was prominent.

To get a count on the Canvasback and a few Redheads, I was to remai on the west side with the sun to $\mathrm{m}$ back, while Dot worked around th north and east side, then closed i along the south side. In this way, w thought we could double check th shorebirds and keep the ducks mov ing so I could get a look at them. Dc was half-way around the lake on thi planned prccedure when she firs saw the Snowy Plover. Here is he story:

"I was near the Black-bellie Plovers and some Sanderlings whe I saw a very white, small shorebir which I thought at first was a Pipin Plover. When the bird turned so cculd see its entire white front, knew almost immediately I wa looking at a Snowy Plover. A fer days previcusly while birding : Strawberry Lake:s with Margare Belcher, Lucy Murray and Bob Nerc we had seen both the Semipalmate Plover and the Piping Plover. It wa then that Bob Nero had told us $t$ look for a bird with a broken nec: ring, very white down the front, an we'd have a Snowy Plover. Of course we had not been expecting to see Snowy Plover at Strawberry Lake or elsewhere in the province, but thi reminder of what to look for mus have been fresh in my mind.

"I had Peiterson's western guid along and for the next 15 minutes studied the bird through $7 \mathrm{X}$ bino, culars and checked all the fiel marks. However, although I got $t$ within 30 feet, I was unable to se the plover's legs. It peered at $m$ from a depressicn and when I move in still closer to try to get a look a the legs, it flew across the lake, land ing south of my husband.

"I knew I had a rare find, so started to run. If my husband coul get a look at it, we could compar notes. I really was quite excited be cause I felt sure the Snowy Plove 
was not on the Saskatchewan checklist."

While I had been working on the Canvasbacks, I could see that Dot had stopped and was giving some particular bird an extra-long study. I also saw her running and was disturbed because the Canvasbacks were going into flight. I finished the count and had about 185 Canvasibacks and 20 Redheads. Meanwhile, the plover which had flown in from across the lake had attracted my attention and as it moved leisurely along the shore, passing to within 40 feet, I was able to study all of its field markings. When Dot came within shouting distance, I yelled: "There's a strangelooking plover down the beach about one hundred yards! Where is Peterson's?" Dot told me she thought it was a Snowy Plover and we should phone or try to contact some of the birders in Regina for confirmation. After referring to Peterson's, I agreed with her that here was a Snowy Plover and at once we set out to find a phone.

Before long we had alerted a number of birders and had left word for Bob Nero to try to get to Buck Lake, hoping to obtain the backing of several observers and possibly even a specimen. We returned to Regina at 5:00 p.m., and an hour later picked up Mrs. Ruth Tempel and drove back to Buck Lake. Ruth and Dot started around the lake and before long, almost at the original place, they spotited the Snowy Plover. The wind had shifted to the east and the lake was choppy. At about this time, Elmer Fox drove up with his family, Mrs. Fox, Reg and Doug. Fortunately for science, Elmer possessed a collecting permit and a suitable gun. I directed Elmer and his son, Reg, around the south end of the lake, pointing out about where I thought Ruth Tempel and Dot had the plover located. In a half hour and after much extremely fine stalking, the Foxes flushed the plover and Elmer brought it down with one well-aimed shot, thus positively establishing the occurrence of this species so far from its usual haunts.

Within a few minutes after this tense drama, other observers arrived, including Dr. and Mrs. George Ledingham, Bob Nero, Robert R. Taylor and Miss Carla Stein. Soon we all had a close look at the Snowy Plover. Though there were some who were sorry the bird had to be collected, all agreed that cbtaining the specimen was scientifically desirable.

\section{LITERATURE CITED}

American Ornithologists' Union. 1957. Checklist of North American birds. Fifth ed. 691 pp.

Bent, A. C. 1929. Life histories of North American shore birds (Part 2). Nat'l. Mus. Bull. 146, $412 \mathrm{pp}$.

Peterson, R. T. 1961. A field guide to western birds. Houghton-Mifflin Co. 366 pp.

\section{First Specimen Record of Pine Warbler for Saskatchewan}

by Margaret Belcher and Robert W. Nero, Regina

A "million dollar" rain, welcomed by farmers across the prairies after a dry spring, began to fall in Regina on Saturday evening, May 2, 1964. Two days of heavy showers followed, and already by. Sunday, May 3, waves of migrant sparrows, thrusihes and warblers were "grounded" in the city. Large flocks of Myrtle Warblers were watched in the rain on Sunday and Monday, flying down from the branches of the leafless trees to feed on the lawns and roadways in the Legislative grounds. With the Myrtles on Sunday, May 3, were small numbers of Orange-crowned Warblers, several Black-and-white Warblers and a Blackpoll Warbler, and the first of the season's Northern Waterthrush. Then on Monday, May 4, Palm Warblers were noted, and a first Yellow Warbler (the earliest recorded spring arrival for the Regina area). Naturally, Regina birders spent considerable time in the Legislative Grounds observing this unusual concentration of warblers, and on Tuesday and Wednesday we were still taking sandwiches to eat in the park so that we could watch them at the noon hour.

The early arrival of several of the warblers-Yellow Warbler on May 4, and Ovenibird on May 6, was an in- 